\title{
CLASH OF WEST AND EAST CIVILIZATIONS IN QUR'AN INTERPRETATION
}

\author{
Ahmad Atabik \\ STAIN Kudus, Central Java, Indonesia \\ atabik78@gmail.com
}

\section{Abstract}

This article describes the clash of west and east civilizations from the perspective of the Qur'an interpretation. As is well known that the Qur'an reveals a clash of civilizations between the West which is represented by the Roman and the east are Persian. The clash occurred for many years. This war began with the triumph of Persians, the Qur'an clearly interpreted that nine years later the Roman defeat the Persian. Roman Empire which is meant by ar-Rum is the Kingdom of Eastern Roman centered in Konstantinopel, not the Western Roman kingdom centered in Rome. The West Roman kingdom, before the events, recounted in this verse occurs has collapsed in $476 \mathrm{CE}$. The Romans are Christians (people of the scripture), and the Persians religion Majusi (idolaters).

Keywords: Clash of Civilizations, Qur'an Interpretation, Roman, Persia. 


\section{Abstrak}

Artikel ini menjelaskan tentang benturan peradaban Barat dan Timur dari perspektif penafsiran al-Qur'an. Seperti diketabui babwa al-Qur'an mengungkapkan benturan peradaban Barat yang diwakili oleh Romawi dan Timur adalah orang Persia. Bentrokan terjadi selama bertabun-tahun. Perang ini dimulai dengan kemenangan Persia, al-Qur'an menjelaskan babwa sembilan tahun kemudian Romawi mengalabkan Persia. Kekaisaran Romawi yang dimaksud dengan ar-Rum adalah Kerajaan Romawi Timur yang berpusat di Konstantinopel, bukan Kerajaan Romawi Barat yang berpusat di Roma. Kerajaan Romawi Barat, sebelum kejadian, diceritakan dalam ayat ini terjadi benturan pada tahun 476. Bangsa Romawi Kristen (abli Kitab) dan orang Persia beragama Majusi (penyembah berhala).

Kata Kunci: Benturan Peradaban, Interpretasi al-Qur'an, Romawi, Persia.

\section{A. Introduction}

Civilizations are something that is identical with the idea of social progress, both in the form of the victory reason and rationality against the dogmas and doctrines of the religion, the degradation of traditional local norms and rapid development of the natural sciences and technology. All things, in the form of deeds and thoughts of human beings, could be released from the civilizations. So the concept of civilization is included all. A high civilization should be able to maintain the majesty of Dam, give satisfaction toward the physical, psychological aesthetics and human creativity. Therefore, he necessitates the flexibility of mutual support between man and his civilization.

Discuss the problem of understanding of civilization, cannot be removed from the elements of civilization 
itself, the man and its breakaway. Many understanding of civilization (bad̦arah) which developed until today, based on the ideas of experts or in terms of the Bible. We will try to analyze to better understand the fact of civilization that looks good in the treasury science and in our lives as the man who played a big part in the civilizations that exist in this world. Of course along with the development of this mindset and man itself, understanding this civilization continue to get the addition of adding so that the sense is more can include from all widened the life of a society where civilization itself grow and develop.

Civilizations that have been produced and left man to surmount changed with other forms. Change from one generation to another generation. Even civilizations are just the history of merely when human beings who create civilizations could not maintain, or destroyed along with the defeat in the war against the owner of the other civilizations. Based on the explanation above, this article will define ecological and presents information related to the civilizations that appear in the Western world, in this case, is the Roman Empire and civilizations shown in the world of the east, namely Persia. How to happen clash between the two civilizations (Romans and Persians) in the war that went over the years. And how the Qur'an that has been described by the expert's interpretation describes the clash of two civilizations.

\section{B.Discussion}

\section{The Term Western Civilization and East}

Civilization in English called civilization, while in Arabic called with hadarah. The term of civilizations is often used and is used to indicate the opinion and our judgment against cultural development. At the time of the development of the 
culture reached its peak that the substantial elements of the culture of the fine, beautiful high, polite, exalted, etc. and then the owner of the cultural society is said to have a high level of civilization and exalted.

Huntington gives the definition that civilizations are a comprehensive identity from the culture, identified through the elements of the common objectives, such as the Bible, history, religion, customs institutions or through selfidentification that subjective. Journeyed from this definition, then the American public-specially the United Statesand Europe that so far is joined by discussing, culture and religion can be classified as one of the civilizations, the western civilization. ${ }^{1}$

Thousands of years of human civilization continues to run until the emergence of ancient Egyptian civilization which is known as the oldest civilizations in the East, around 4000 years before CE. In this society has found a lot of progress in different areas, including related to scholarly qualifications, social, etc. The science of mathematics for the first time has been found in this land and then appears again engineering science and Astronomy. It had a great impact on the progress of civilization in India and Iraq in the science of mathematics, Greek in engineering science and Arabic in the science of algebra (mathematics). This phenomenon occurs because the Indian civilization, Iraq, the Greeks and the Arabs began to grow earlier and go after the ancient Egyptian civilization thousands of years. ${ }^{2}$

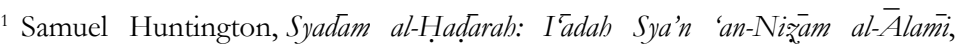
translated by Thalhah ash-Syayib from The Clash of Civilization and the Remaking of World Order (Cairo: Dār al-Miṣriyah, t.t.), p. 68-69.

${ }^{2}$ Mansyawi 'Abd ar-Rahman, Fi Tarikh al-Fiker al-Falsafi (Cairo: Dār as-Ṡaqafah al-Arabiyah, 1999), p. 212. 
Then Babylonia and Syria (the civilizations of East) appears with the development of his knowledge that is more or less across culture with Ancient Egypt because they edged average of livelihoods as traders so that various knowledge has been developed in the land of Babylonia and Syria. As mathematics, astronomy, forecast weather and annual calendar. The progress there at the time finally continued to grow and expand to Persia, India, and China. In a society of India has developed the science of mathematics with various parts. The science of logic for the first time established with various subject discussion before the emergence of the science of logic compiled by Aristotle. Many found the philosophical thought that more complex and much more advanced than the previous civilizations. The scholars of India known as the teacher of Pythagoras (Mathematicians) from Greece, unfortunately, it many is violated by his successors, with said that Pythagoras is the founder and the pioneer of science mathematics. So also the clerics India earlier, they are "teachers" Arabs in the science of mathematics, handicap, and astronomy. ${ }^{3}$

After a long time of human civilization carving his excellency in the East, West appears several thousand years later. A new civilization was started with the emergence of philosophy studies in the sixth century BCE. Thales is recognized by Aristotle as the first Greek philosopher vast philosophy developed in this country (Greek) through his famous philosopher Socrates, Plato, and Aristotle which ends in a corner of the city named "Athens". ${ }^{4}$

Western civilization has been changing the world with the existence of the new civilization that begins from the Greek and Roman, they recite the slogan "West is a pioneer

${ }^{3}$ Ibid., p. 213.

${ }^{4}$ Huntington, Syadam al-Had̦arah, p. 68. 
of science and culture". Yet history has recorded many advanced civilizations and developed in parts of the Middle East only when compared with the city of Athens that the amount of completely comparable with Ancient Egypt, Babylonia, Syria, Persia, India, and China. Here the European nations were of the opinion that the civilization is in the East is only a striking resemblance alone and bound (related) with religion or creed the creed of their society, so that it can be said at the start of the development of science and culture man. But the phrase was rebutted by the people of the east, saying that the history of walking from the past (ago) to a new period (front). The phenomenon is to the east is the time travel that preceded the west, then all the influence of will come from the old to the new. ${ }^{5}$

The Qur'an would not escape provides an overview of this civilization. In Q.S. al-Qasas [28]: 38, "Pharaoh said, 'Then burn clay for me o Haman (to make bricks), then make the building is high for me so that I can be up to see His Lord Moses. This verse describes how the Pharaoh has made a building that high civilization, which by interpretation is called ilmi experts as a pyramid." More than that, Fazlur Rahman (1983) find the study that according to the Qur'an, there is a "discontinuities" essential between civilizations that elders and dead and civilizations that came to replace it. In the Qur'an, statements such as "then we create a new generation" often found (see Q.S. al-An'am [6]: 6, also Q.S. al-Mu'minun [23]: 31), also the statement that "We will leave the world to the new nation that more right." (Q.S. al-Anbiya' [21]: 105, also Q.S. al-Ahzab [33]: 27). ${ }^{6}$

The alternation of generations raises new civilizations that do not lose value with the previous civilizations. In the

\footnotetext{
${ }^{5}$ Ibid., p. 69.

${ }^{6}$ Fazlur Rahman, Tema Pokok al-Qur'an (Bandung: Pustaka, 1983), p. 189.
} 
west and east of the Roman, appears Persia. Qur'an also implicitly mentions two civilizations, especially the Roman civilization (Western civilization). Even the Roman Empire was created as one of the letters in the Qur'an, namely the Surah ar-Rum. In the early surah, ar-Rum is described how the Roman Empire physical contact or the war with Persia dakhsyat (the civilisations of East). Description details about the clash of civilisations Roman Empire (west) and Persian (east) will be described in the following sections.

\section{Romans Before Islam}

The Roman word is derived from the Romans which is the name of the city which became the capital city of the Republic of Italy now. This city is located at the west side edge of the river from Tiber River, who built by Romulus on 2120 years before the Prophet Jesus was born. In Arabic Roman words are called ar-Rum, this word even becomes a letter that was found in the Qur'an. Before Islam came, the Roman kingdom is divided into two, the Eastern Roman and the West Roman. The land of the land of Egypt, Palestine, and Syria at the age is in that the power of the Eastern Roman centered in Byzantium. Meanwhile, Western Roman territory limited Sea Tirrenia, the east limited Ionian Sea, and the Adriatic, the north is restricted Switzerland and Austria, and the south is restricted by the island of Sicily and the Mediterranean. ${ }^{7}$

Related to the form of the state is an outline of the history of ancient Rome divided into three: First, the Kingdom (750-510 BCE) is a time when a king accompanied by the senate (representatives of the tribes around the Romans). Second, the days of the Republic (510-31 BCE) namely days, when Rome grew from a small city state, became the republic

${ }^{7}$ Hamka, Tafsir al-Azhar: Diperkaya dengan Pendekatan Sejarah, Sosiologi, Tasawnf, Ilmu Kalam, Sastra, dan Psikologi (Jakarta: Gema Insani Press, 2015), p. 30. 
of that area. Third, the days of the Empire (31 BCE until its collapse) namely the Mighty Monarchy. ${ }^{8}$

The composition of power, initially, Roman led by the king who is assisted by the Senate. When the Roman Republic was first built in the 500 BCE, the king is replaced by two people called the consul, while the senate is still there. The Consul assisted by the senate as the advisory board. The Senate consists of families rich in the Roman Empire. The Consul often carries out what is proposed by the Senate. There are also some core officials in the Roman Empire, on duty oversees the city, some judge cases, some others regulate the market or port. In addition, there Tribune, namely the people in the Senate that represent the poor people. Tribunus selected by the Council. After the Roman Empire conquer various areas that are far from the city of Rome, they implement the system of the province. Each province led by Governor. The governor had control over the troops in his province.

Roman Empire by successive and alternatingly ruled by an emperor who aging adherents of the religion of ignorance worshiped the stars and gods as an extension of the belief of the Greeks. Thirty years before the birth of the prophet Isa, Rome a kingdom or the position of the great, especially in the days of Emperor August, the emperor of the great emperor since the days of Tiberius, Caligula and Claudius Rome reach the peak of civilization, which exceeds the days of ancient Greece. At the time of the Prophet Jesus and religion that he taught to the Romans. But Emperor Nero, preventing the development of the religion of the Prophet Jesus went into the country. In vapor, Roman experience dominated determination in power until the reign of the emperor

${ }^{8}$ Rika Moniarti, Sejarah Peradaban Kuno (Bandung: Mitra Means, 2002), p. 37-38.

${ }^{9}$ Anne Marshal, Era Bangsa-bangsa di Dunia (Jakarta: Experts Feast, 2003), p. 22. 
Deliriants in the year 283. He divided the Roman kingdom shall be for two parts according to the politics; namely the Eastern Roman and Roman West. Emperor Constantine first specify city Byzantium so the capital of the Eastern Roman and give the name of the capital city of Konstantinopel. ${ }^{10}$

This is the Emperor who gives freedom of Christianity developed in his land, years 313 M. In the year 391 Roman division decision into two parts. The Eastern Roman named Byzantine, Western Roman capital was originally specified Ravena, finally Terif moved to Milan. Since then the Roman Empire the West to withdraw and the Byzantine increased the glory. When led by the Pope Gregory, he tried hard to oppose the influence of the Byzantine. The Pope Kristian Gregory power from the year 590-604 M. The Eastern Roman or Byzantine kingdom increased to develop its influence to the east and Asia Minor. ${ }^{11}$

The effort of the pope this is, Rome West side rise up again under the authority of the highest religious leaders, the more we know the name of the Catholic Church, as well as the Eastern Roman or Byzantine, develop continues its authority to the east, so confrontation is begun with the Iranian power (Persian). In the days of the Emperor Heraclius written by the Arabs with the title 610-641 Hiraqlu (M). The contradiction between the Roman Empire which by the Arab called the Rum with the Persians great. In the days of the religion of Islam began to appear and grow in the land of the Arabs. ${ }^{12}$

\footnotetext{
${ }^{10}$ Ibid., p. 23.

${ }^{11}$ Ibid., p. 24.

${ }^{12}$ Pennys Clarke, Dunia Sejarah Singkat (Yogyakarta: Golden Books, 2008), p.
} 41. 


\section{Persia Before Islam}

When talking about the Persians, immediately our memories are mapped on the country now called Iran. Whereas the fact is included in the ethnic groups is not only the state of Iran, even though it is the majority of the Persians are in a country of Iran, the Persians also became a minority in the countries around Iran, such as Afghanistan, Tajikistan, Uzbekistan, Kuwait, Turkey, Uni Emirat Arab, Iraq, and also some countries in the Middle East.

Before Islam came and conquered the Persians, this nation has its own culture. The greatness of this nation even can be likened to the Roman Empire at that time. They have been enjoying their existence as a nation that stands on its own for centuries, and never represents a military force that organized with good, also had been at war with the Roman Empire for more than 400 years. ${ }^{13}$

According to the data from the history of the Persian civilization had emerged and established the empire since 700 century BCE (Media empire or Akhemeniyah). This empire has become a symbol of the Persian land civilization. In around $648 \mathrm{BCE}$, an Emperor named Great Koresh, put laws regarding the rights of humanity, written on the artifact known as the Cylinder Koresh. He is also the first government who wore the title Agung and also Shah Iran. In his day, slavery banned in the areas of his conquests (also known as the Persian Empire.) This idea and then give great impact on human civilizations after his day. In the year 330 BCE Akhemeniyah Empire attacked by KerajaanYunani that in the lead one general from Alexander Agung named Seleucus and born the new government of Persia namely

${ }^{13}$ Philip K. Hitti, History of the Arabs (Jakarta: Serambi, 2002), p. 198. 
Seleucus empire from Greece. Seleucus raise itself to the Emperor after Alexander the Great died. ${ }^{14}$

After the Empire collapsed, incited Sleuths Parthian empire. The emergence of this emperor begins with Arsacids Dynasty that unites and rule the Iranian plateau, which also subjected the eastern region Yunani at the beginning of the third century BCE, and also Mesopotamia between the year $150 \mathrm{BCE}$ and $224 \mathrm{M}$. Parthia is also sworn enemies Roman Empire in the east and limit the danger of Roman Empire in Anatolia. The soldiers of Parthia divided over the two groups of horsemen, and armored army cavalry, and carry heavy weapons and soldiers armed horsemen lightweight, and horses swift moves. Meanwhile, the Roman soldiers too dependent on infantry, cause difficult Roman to defeat Parthia. But, Parthia lacks the technique in the war renegades, cause them is difficult to control the area of the subject. This causes the two sides failed to defeat one another. Parthian empire stood upright for five centuries (ended in the year $224 \mathrm{M}$ ) and final king defeated the hand of the protection empire, namely Sassanian. ${ }^{15}$

Ardashir I, the first Sassanian Shah Empire, is a pioneer of the early rebuilding economic and military Persia. Territory covers the area of Iran, Irak, Suriah, Pakistan, Asia Tengah and the region Arab. In the days of Khosrau II (590-628), this empire extends to the Egypt, Jordanian, Palestina, and Lebanon. The Sassanian named their empire Eranshahr (or Iranshaehr, "mastery of the Aryans"). At the time this is the Persians often even continue Meerut confrontation and conflict during the six hundred years with the Roman Empire. Finally, Persian culture empire collapsed

${ }^{14}$ Rizem Aizid, Singa Padang Pasir Menerkam Amerika dan Sekutunya (Jakarta: Palapa, t.t.), p. 213.

${ }^{15}$ Ibid., p. 214. 
at the hands of Muslims began from al-Qadisiyyah war (632 M) in Hilla, Iraq. Rostam Farrokhzād, a general of Persia, criticized for its decision to go to war with the Arabs in the Arab world itself. The defeat of Sassanian in Iraq cause their army incoherent and finally gave way to the future that Islam over the Persians. ${ }^{16}$

Meanwhile, on the other side of the belief, Persia culture since ancient religion have named Zoroaster, by the Arabs known with the name Majusi. The religion of Zoroaster ascribed to a prophet original ancient Persia from the tribe named Spitama Zarathustra who live along the know 674-551 BCE. Since the age of twenty years, he began to tafakkur and explored, focusing on doing good for the people who need him. With zeal and obedient he developed his religion. A king in the city of implementing named King KavibVisshtasva so his followers who obey and faithful, the king went with his realization itself after arguing with Zarashtura. Finally, the religion of Zoroaster became the religion of the Medes and Persians moreover when the reign of Emperor Cyrus and Darius the religion of Zoroaster experiencing the golden age. But when Iskandar Agung conquered Persia, religion is lost and replaced with Greek religion at that time. After the Sasanid Empire holding the reign of religion back rise. Finally, after Islam into Persia years $638 \mathrm{CE}$, religion Zoroastrians or Majusi became lost and the community almost all converted to Islam until now. ${ }^{17}$

${ }^{16}$ Ibid., p. 214.

${ }^{17}$ Marshal, Era Bangsa-bangsa di Dunia, p. 245. 


\section{The Interpretation of Q.S. ar-Rum [30]: 1-5}

\section{a. The Miraculous Nature of "Prediction" the Qur'an}

There is a difference in determining the aspects of the Qur'an miracle. Muslim thinkers of Egypt, Fatimah Ism'il in his book the Qur'an was an-nazr al-'aql for example, more stressed that the miracle of Qur'an there on the side of the rationality. The Qur'an, he said, always calling people using the language of reason. The most extreme example is when the pagans demanding Muhammad bring the verses (signs) a matter of sensory, with emphasized the Qur'an reply to these demands with the rational answer (Q.S. al-'Ankabut [29]: 50-51). Besides that, the Prophet called his people while asserting that the Qur'an is not the type of the miracles trifling reason and thinking culture. But in the form of the verses that requires tadabbur analyzes and thoroughly in-depth will fill her womb. ${ }^{18}$

While according to Abdul Wahhab Khallaf, the miracle aspects of the Qur'an, among others: First, with integrity and harmony between the expressions, the meaning of the meaning of the laws and concepts that are taken and they offer. The Qur'an, with 6000 more verse that it contains when he revealed something to told the good faith, morals, law, as well as some of the basic concept of the universe, social life and individual, use expressions and editor in chief of a various pattern. In this diversity not found the existence of conflict and contradiction to one another. Second, the suitability of the verses to scientific findings. Third, the womb space about the events that are known only by the most know about the unseen. Four, fluency the words he chooses, beauty

${ }^{18}$ Fathimah Isma'il, al-Qur'an wa an-Nazr al-'Aq7i (Cairo: Dār asy-Syurūq, 1997), p. 189. 
editors who use as well as the strength of the influence in its wake. ${ }^{19}$

Meanwhile, M. Quraish Shihab in his book Mu'jizat alQur'an explains that there are other miracle aspects namely aspects of the preaching of events yet to happen when the Qur'an was revealed. This means that is predicted incident after the revelation of the verses that exactly in accordance with the image as described in the Qur'an. In this case, the Qur'an reveals the events that will happen, both in this world and in the hereafter. The events described the Qur'an will happen, and some have been proven in history. ${ }^{20}$

For example that can be taken as an example here is: had defeated the Romans (Q.S. ar-Rum [30]: 1-3). This example to the core of the discussion of this paper. While another example is located in Q.S. al-Qalam [68]: 10-16:

This means: and ye shall not follow everyone that many swear again despised. That many insults and to and fro bring slander. Very reluctant to do good, which is beyond the limit again many sinned. A rigid coarse, then notorious prisoner/recognized parents. Because he has a lot of wealth and children. When our revelations are recited unto him, he said, "(Tales of the ancients. We will mark it in the trunk of his nose.

The attributes of the related the Qur'an above are concerned with a polytheist namely al-Walid ibn al-Mugirah, through the verse of the Qur'an provides two information unseen as well. The information verse 13 is the news of the unseen of the past, and verse 16 informs the news of the unseen future. In verse 13 , there are zanim, which by many experts interpreted as someone who is recognized by

${ }^{19}$ Abdul Wahhab Khalaf, 'Ilm Ușül al-Fiqh (Kairo: Maktabah ad-Da'wah alIslāmiyyah, 1990), p. 28-31.

${ }^{20}$ M. Quraish Shihab, Mukjizat al-Qur'an Ditinjau dari Aspek. Kebahasaan, Isyarat Ilmiah, dan Pemberitaan Gaib (Bandung: Mizan, 2007), p. 26. 
the parents as children, not recognized. In other expression, children who do not know by his father, then there are other people who acknowledge as children.

M. Quraish Shihab quoted scripture interpretation of al-Futūhat al-ITahiyyah explains that Sulaiman ibn Umar alJamal commented about the above verse as follows: ${ }^{21}$

Al-Walid the son of al-Mugirah raised the son by the "father" and his ascribed to al-Mugirah, after during for eighteen years is not known who his father. When the above verses down, al-Walid said to his mother, "Muhammad (through the Qur'an) with nine properties and all I understand, except one (namely zanim). Explain to me, if not I beheaded your neck." Then his mother answered, "Behold thy impotent father, I worry about the loss of wealth and then I related (sex) with shouts at what he hears nothing, and you are the sons of the shouts at what he hears nothing."

The Qur'an provides information that couldn't see, which is not known to the Prophet Muhammad preached before the Lord unto him. The Qur'an reveals the secret of the individual who is very hidden even concerned himself does not know it. Information that couldn't see next related news of the future al-Walid implied in verse 16 in that surah. The verse informs us that will be given a mark on the nose al-Walid. And most righteous God, because in the war of Badr in the second year of Hijriah, al-Walid involved and injured on its nose, so that flies away throughout his life. ${ }^{22}$

This miraculous aspect including problem notification unseen (something that is not in the know is not real or hidden). Man will not be able to open the veil the veil of the unseen because human knowledge is limited to five senses while sensing as a filter from what was arrested by five senses. The disclosure of the problem is hidden in the Qur'an is

\footnotetext{
${ }^{21}$ Ibid., p. 220-221.

${ }^{22}$ Ibid., p. 221.
} 
a proof that he is rejecting God is not made the Prophet Muhammad, such as the accused by the oriental. This means that in the expressed the Qur'an about the problem of the unseen is the past events that are not in the know by man except by revelation, events that will come, and past events now that has not been in the know by man. ${ }^{23}$

The problem of the unseen, there that has been proven to be the truth and there has not yet been revealed, now the problem is how to address the news of the unseen in the Qur'an that has not yet been revealed, the attitude that should be done by the people of Islam still believes the news, because however also the news that comes from God and everything that comes from God must be true, now not disclosures the occult news due to the two factors: First, human knowledge is limited. Second, not time for known or revealed. ${ }^{24}$

\section{b. Asbāb an-Nuzūl of Verse}

This verse was revealed when Sabur (Persian emperor) successfully defeated the Roman soldiers and successfully took over the lands of Syam and other parts that belong to the territory of the kingdom of the Roman Empire from the land of the Arabian Peninsula of Arabia, also some may have the region of the Roman Empire, so that the Roman Emperor named Heraclius was forced to withdraw and fled to the city of Konstantinopel. It is surrounded by a sense of Sabur and his troops in the city of Konstantinopel in the southwest that long enough, but in the region, an invasion of the Roman kingdom successfully taken back by Heraclius from the hands of the Persians.

In Musnad Aḥmad, Imam Ahmad ibn Hanbal said, have told us Mu'awiyah ibn Amr, have told us of Abu Ishaq, from

${ }^{23}$ Manna' al-Qattan, Mabăhis fi 'Ulum al-Qur'an (Cairo: Maktabah at-Taufiqiyyah, 2000), p. 352.

${ }^{24}$ Ibid., p. 354. 
Sufyan us. Queen, from Habib ibn Abu Umrah, from Said ibn Jabari, from Ibn Abbas. That has been said in relation to the meaning of His word, Q.S. ar-Rum [30]: 1-3. The defeat of the Romans at the nearest land. Ibn Abbas reported that formerly the pagans feel like when the Persians have victory over the Roman Empire because the Persians are idolaters with them. While Muslims feel like when the people of the Roman Empire which have victory over the Persians because of the Roman Empire is the Book with them. Then, Abu Bakr told it. Then he narrated: Remember, behold them (the Roman Empire) will obtain the victory. Then Abu Bakr told it unto the idolaters. Then they say, "Let us determine the time limit for you and us. If we guess right, then we get (wealth) and (wealth); and if your guess right, you also get this (wealth) and (wealth)." Then the period specified by Abu Bakr is five know and found the Roman troops have not obtained the victory also. Then Abu Bakr told the Prophet. The messenger replied, "Why did you set the time for the ten years (above five years)?" Sa'id ibn Jubair said that the time under septum years, then the Roman Empire have victory. Sa'id ibn Jubair said that this is what is meant by His word: "Alif Làm Mim had defeated the Romans in the land that is closest, and they defeated will win" (Q.S. ar-Rum [30]: 1-3), until with His word: "And He is Exalted in Might Most Merciful" (Q.S. ar-Rum [30]: 5). ${ }^{25}$

\section{c. The Interpretation of Q.S. ar-Rum [30]: 1-5}

As has been explained that are the focus of the study is Q.S. ar-Rum [30]: 1-5. This verse explains that the nations (civilizations) Roman Empire was defeated by the nation (civilizations) Persians in the land close to the city of Mecca, which is the land of the Syrian. Some years later after

${ }^{25}$ Abu al-Fida' Ibn Katsir, at-Tafsir al-Qur'an al-Až̀im (Beirut: al-Maktabah al-'Aș riyyah, 1997), Volume III, p. 396. 
they defeated, then the Romans would defeat the Persians as a reward for defeat. What is meant by the Romans in this verse is the Kingdom of Eastern Roman centered in Konstantinopel, not the Western Roman kingdom centered in Rome. The Roman kingdom of the West, long before the events recounted in this verse occurs, has collapsed, namely in 476 CE. The Romans religious Christians (abl al-kitab), is the Persians religion Majusi (idolaters).

In interpreting Q.S. ar-Rum [30]: 2, asy-Syaukani explained that the Persians conquered the Roman Empire, then the unbelievers Makkah tidings, and they say, "The people who did not have the Book had defeated the people who have the book." They also boast against Muslims, and say, "We will also defeat you as Persia defeated the Roman Empire." On the other hand, you Muslims sebih like the Roman victory over the Persians, because the Roman Empire was the scribe. On verse 3, asy-Syaukani explained that after the Persian victory over the Roman Empire, then the Roman Empire will be defeated the Persians (Majusi), in some years (nine years). While verse 4 and 5, asy-Syaukani explained that on the day of the triumph of the Romans over the Persians, the believers rejoice with the help of God for the Roman Empire. For God help whoever He wills. ${ }^{26}$

Meanwhile, Ibn Katsir, an expert interpretation is also the historian, in his interpretation explain at length about the history of the Roman wars and Persia. He stated that the Romans derived from the descendants of Isa son of Prophet Ishaq, they are sons of the uncle of the children of Israel, and known by the name of "the yellow-skinned (white)". They initially keep to the religion of the Greeks. The Greeks

${ }^{26}$ Muhammad bin Ali bin Muhammad asy-Syaukani, Fatḥ al-Qā̄ir al-Jami’ baina Fannäi ar-Riwäyah wa ad-Dirayah min Ilm at-Tafsir (Beirut: Dār Ibn Hazm, 2014), Volume III, p. 437. 
derived from the descendants of Yafis ibn Noah, the sons of the uncle of their ancestors the Turkish nation. They worshiped the stars that circulate through the amount of which there is seven fruit. The Roman Empire has initially adopted their religion until the time he sent the prophet Isa, three hundred years later. ${ }^{27}$

The king from among those who have successfully rule the whole of the area of the land Syam with the Arabian Peninsula of Arabia called with the epithet of the emperor. The first king who embraces religion Christians from among all the kings of the Roman Empire is Constantine ibn Qastus. His mother was named Mary al-Hailaniyah al-Gandaqiyah from the land of Haran. In the beginning, he first entered Christianity and invites his son to embrace the religion of Christians. The reconstruction of the Roman Emperor is an expert philosophy, finally, he followed the invitation mother. Slowly, almost all Roman society adheres to the teachings of Christians. Each time the Emperor died, his position is replaced by his successors until the last emperor named Heraclius. Under the leadership of the Roman Empire reached the golden age so that is comparable to the kingdom of Persia. ${ }^{28}$

Meanwhile, Kisra (King of Persia) control of many of the vast country such as Iraq, Khurrasan, Ray, and other lands not Arabs inhabitants. The name of the king of Persia when it is Sabur nicknamed with the name Zul Aktaf. The Persian kingdom far greater than the Roman kingdom. In the history of sourced from about Ikrimah Ibn has mentioned that the Kisra send assistants and his troops to fight against the Roman Emperor. Kisra besieged the city of Konstantinopel in a long time so that membosankannya. The Christians very

${ }^{27}$ Abu al-Fida' Ibn Katsir, at-Tafsir al-Qur'an al-Ažim, Volume III, p. 397.

${ }^{28}$ Ibid. 
glorifying the city of Konstantinopel, while Kisra is not able to conquer the city because the strongholds that are very strong and is convenient very strategic. ${ }^{29}$

After the siege, Kisra have a trickery. For that he asked to Kisra to go out of his land with the reward some wealth approved by Kisra with requirement that the emperor allowed to apply the requirements according to what he likes. The request was approved by the emperor Kisra, and asking for wealth that many once the amount to Caesar so that there is no a king in this world that are able to fulfill it. The emperor demanded to Kisra to give him the opportunity to come out from the fortress toward the land of Syam and areas of other Roman kingdom with reason will ${ }^{130}$ collect the funds from the wealth simpanannya located in these areas. ${ }^{31}$

When the Emperor Constantine came out from the strongholds, he was accompanied by a number of troops. While Kisra was camped in Konstantinopel with his army waiting for the coming of the emperor back to Konstantinopel. After getting the opportunity of the emperor immediately took his army moving toward fastly to the land of Persia. Arriving in the land of Persia, he and his troops damage and killing the male thereof and the army of the Persian. He continued to do the killing along the way he lives he came up in the capital city of the kingdom of Persia. ${ }^{32}$

When the news came to Kisra, nothing can describe his sad expression turned cheerful besides only Allah swt., and his anger increased overflow toward the capital city of the kingdom of the Roman Empire. Then he launched the attack with all the power and ability that possesses, but effort

\footnotetext{
${ }^{29}$ Ibid., p. 398.

${ }^{30}$ Ibid.

${ }^{31}$ Ibid.

${ }^{32}$ Ibid.
} 
obstacles and vain. After not able to execute the fortress of Konstantinopel, so he went with his army to intercepted Caesar and his troops in the crevice tool Jaihun which is the only way for the emperor to reach Konstantinopel. ${ }^{33}$

The emperor know tactics and he makes a very great deception, has never been tactics was done by a commander of war. For that he put his troops and all the goods that they have succeeded to obtain from the spoils of war in the mouth of the crevice tool Jaihun. Then he ordered to some troops to bring animal food vehicles, dirt and the contents of the stomach livestock. Then he brought his troops through the streets of that climb up to come to the place near the crevice tool Jaihun more or less travel distance one day. Arriving at the top, he commanded the troops to cast all the burden that they carry into the river (which through openings Jaihun). ${ }^{34}$

When the dirt and fodder were swept away by the flow of the River Sam came to the place, then Kisra suspect that the troops who brought the emperor through the streets of. Then immediately he ruled the Emperor returned to the main army and ordered them to move and enter the crevice tool Jaihun with quick steps. Finally the emperor with tracker mortgages Kisra are safe and his troops and came in the fortress of Konstantinopel in peace. Then the day was made by the Christians as the day of the feast. While Kisra and his army of confusion, they know not what they do. The lands of the emperor could not they conquered, while their own land have been destroyed by the Roman troops. ${ }^{35}$

So the victory of the Romans story over the Persians, and this event occurred after the elapsed time of nine years since the victory of the Persians on the Romans. The Great

\footnotetext{
${ }^{33}$ Ibid., p. 321.

${ }^{34}$ Ibid.

${ }^{35}$ Ibid., p. 322.
} 
War between the Roman troops and the Persian, where the Roman troops losing, happened in between Azri'ah and Basra. So according to what is mentioned by Ibn Abbas and about Ikrimah Ibn and besides both. The place is the fringe of the land Syam nearby is convenient to the land of the Hijaz.

\section{Conclusion}

From the explanation above it can be concluded as follows: First, civilization as described by Huntington is a comprehensive identity from the culture, identified through the elements of common objective, such as the Bible, history, religion, customs institutions or through selfidentification that subjective. Second, the Qur'an reveals a clash of civilizations between the West, which is represented by the Roman with the east the presentation is Persia. The clash is a war that occurred for many years. This war began to be won by the Persian (religious Majusi), but as reported by the Qur'an, the hose nine years later the sub stitutionary sacrifice Roman Empire (religious Christians) defeated the Persians. Third, when the Persians conquered the Roman Empire, the unbelievers Makkah happy because those who do not have the Book (Persian religious Majusi) had defeated the people who have the book (Rome). With the defeat of the Roman Empire is the unbelievers Makkah with arrogant states will overcome the believers as Persia defeated the Roman Empire. 


\section{REFERENCES}

Aizid, Rizem. Singa Padang Pasir Menerkam Amerika dan Sekutunya. Jakarta: Palapa, t.t.

Clarke, Pennys. Dunia Sejarah Singkat. Yogyakarta: Golden Books, 2008.

Hamka. Tafsir al-Azhar: Diperkaya dengan Pendekatan Sejarah, Sosiologi, Tasawuf, Ilmu Kalam, Sastra, dan Psikologi. Jakarta: Gema Insani Press, 2015.

Hitti, Philip K. History of the Arabs. Jakarta: Serambi, 2002.

Huntington, Samuel. Syadam al-Had̦arah: I'ádah Sya'n 'anNižă al-Alami, translated by Thalhah ash-Syayib from The Clash of Civilization and the Remaking of World Order. Cairo: Dār al-Mișriyah, t.t.

Ibn Katsir, Abu al-Fida'. at-Tafsir al-Qurªn al-Až̈im. Beirut: al-Maktabah al-'Așriyyah, 1997.

Isma'il, Fathimah. al-Qur'an wa an-Nažr al-'AqTi. Cairo: Dār asy-Syurūq, 1997.

Khalaf, Abdul Wahhab. Tlm Ușul al-Fiqh. Kairo: Maktabah ad-Da'wah al-Islāmiyyah, 1990.

Marshal, Anne. Era Bangsa-bangsa di Dunia. Jakarta: Experts Feast, 2003.

Moniarti, Rika. Sejarah Peradaban Kuno. Bandung: Mitra Means, 2002.

al-Qattan, Manna'. Mabāḅis $\overline{f i}$ 'Ulum al-Qur'an. Cairo: Maktabah at-Taufiqiyyah, 2000.

Rahman, Fazlur. Tema Pokok al-Qur'an. Bandung: Pustaka, 1983.

ar-Rahman, Mansyawi 'Abd. Fi Tarikh al-Fiker al-Falsafi. Cairo: Dār as-Saqafah al-'Arabiyah, 1999. 
Shihab, M. Quraish. Mukjizat al-Qur'an Ditinjan dari Aspek Kebahasaan, Isyarat Ilmiah, dan Pemberitaan Gaib. Bandung: Mizan, 2007.

asy-Syaukani, Muhammad bin Ali bin Muhammad. Fath alQadir al-Jami' baina Fannäi ar-Riwàyah wa ad-Dirayah min Ilm at-Tafsir. Beirut: Dār Ibn Hazm, 2014. 